\title{
Walter E. Block
}

Loyola University New Orleans, United States

\section{Voting: Rejoinder to Casey, McElroy, Ward, Pugsley, Konkin and Barnett}

$24 / 2018$

Political Dialogues

DOI: http://dx.doi.org/10.12775/DP.2018.002

\begin{abstract}
:
There is a debate within the libertarian intellectual community regarding the legitimacy of voting in democratic elections. Critics say that such behavior is incompatible with this doctrine. The present paper defends voting from a libertarian perspective. It is an attempted refutation of the views on this matter of Casey, McElroy, Ward, Pugsley, Konkin and Barnett.
\end{abstract}

Key words: Voting, democracy, justice, libertarianism

\section{Introduction}

The only legitimate democratic vote occurs when all those concerned agree to be bound by the results of the election. For example, the chess club is divided as to whether they should meet on Tuesdays or Wednesdays. They all agree to be bound by the ballots of the entirety of the membership. That type of election is entirely compatible with libertarianism. But, are there any others? For example, what about the political vote, in a democracy such as the U.S.? Can taking part in the political process be reconciled with the non-aggression principle (NAP) of libertarianism, given that from a libertarian anarchist point of view, the government necessarily violates rights?

If I had to radically shorten my argument in favor of political voting, I could do so in two words: "Ron Paul." Indeed, I am sorely tempted to merely list the cases made by all libertarian opponents of voting, respond to each with these two words, over and over again, and thereby rest my case. Why? Well, Dr. Paul has had three careers. The first was as a doctor. How many people did he convert to libertarianism during his life as a physician? I am not sure. I doubt records were kept. My best estimate? He promoted our philosophy to a few dozen people, mostly through force of will, and osmosis. In this third and present career, he has taken on the role of President of the Institute for Peace and Prosperity. How many have come to our banner as a result of this initiative of his? Again, I do not know. I am unacquainted with any statistical records in this regard. My guess would be a few tens of thousands, perhaps a few hundreds of thousands. 
But it was in his second career as a politician that my estimate is that he introduced not millions of people to liberty and good (Austrian) economics, not tens of millions, but hundreds of millions. Maybe even a billion souls have heard of the freedom philosophy due to his magnificent and herculean efforts as a congressman and later candidate for the Presidency of the U.S. Had he succeeded in this latter goal of his, my expectation is that within the first five minutes of his term of office who would have begun the process of bringing all U.S. troops home, where they belong, and thus saved countless numbers of innocent lives. So, yes, in response to each and every argument against voting, against the political process itself, I am sorely tempted to offer this two word response: "Ron Paul." But, with my gift of gab, I find I cannot so restrain myself. Let us then consider, and reject, a whole host of arguments in behalf of the non-voting stance.

We consider, and reject, the perspective of voting from a libertarian point of view, of Casey (section II), McElroy (section III), Ward (section IV), Pugsley (section V), Konkin (section VI) and Barnett (section VII). We conclude in section VIII.

\section{Casey}

Casey (2017) offers these five reasons; my comments on each are interspersed with them:

1. "Voting in a political election is unethical. The political process is one of institutionalized coercion and force. If you disapprove of those things, then you shouldn't participate in them, even indirectly."

Ethics is beyond the purview of libertarianism. We are only interested, in the latter capacity, as to whether an act should be legal or not. But as a matter of pure ethics, I find it hard to dismiss a process that brought libertarianism to maybe billions of people. Yes, of course I disapprove of "institutionalized coercion and force." But if the goal of the vote is to reduce or eliminate these scourges, it is not clear to me why this should be considered unethical.

2. "Voting compromises your privacy. It gets your name in another government computer database."

Yes, this is a valid liability to entering the ballot box. But we ${ }^{1}$ are already in so many, many governmental data bases, it seems that one more would be only marginally harmful. We already have driver's licenses, passports, educational records, we are enrolled in social security and all sorts of medical programs. It seems difficult to believe that this can be the straw that breaks the camel's back. ${ }^{2}$

1 Those of us who are not hippies, or hermits alone in the woods.

2 Also, contrary to the opinion of even some libertarians, there is no such thing as a "right to privacy." This, rather, is an element of wealth, or command over goods and services. See on this: Block, 1991, 2012, 2013A, 2013B, ch. 18, 2016, 2017A, 2017B; Block, Kinsella and Whitehead, 2006; Bonneau, 2012; Rothbard, 1998, Wenzel, 2017. States Rothbard (1998, ch. 16) "But is there really such a right to privacy? How can there be? How can there be a right to prevent Smith by force from disseminating knowledge which he possesses? Surely there can be no such right. Smith owns his own body and therefore has the property right to own the knowledge he has inside his head, including his knowledge about Jones. And therefore he has the corollary right to print and disseminate that knowledge. In short, as in the case of the 'human right' to free speech, there is no such thing as a right to privacy except the right to protect one's property from invasion. The only right 'to privacy' is the right to protect one's property from being invaded by someone else. In brief, no one has the right to burgle someone else's home, or to wiretap someone's phone lines. Wiretapping is properly 
3. "Voting, as well as registering, entails hanging around government offices and dealing with petty bureaucrats. Most people can find something more enjoyable or productive to do with their time."

Happily, at least some people, the ones who supported You Know Who (hint, his initials are RP), found entering the political process "more enjoyable or productive" than engaging in other activities. Otherwise, there would be far fewer libertarians around at present. Hey, if we want to change things, one of the sine qua nons will be to swell our numbers.

4. "Voting encourages politicians. A vote against one candidate-a major, and quite understandable, reason why many people vote-is always interpreted as a vote for his opponent. And even though you may be voting for the lesser of two evils, the lesser of two evils is still evil. It amounts to giving the candidate a tacit mandate to impose his will on society."

It cannot be denied this is a risk. But suppose virtually no one voted; say, less than $5 \%$ of those eligible. What would be the likely government reaction? They would either make it compulsory, fining those who refused, or would offer a subsidy for this practice, higher and higher until they reached the level they wished. Those, while a low vote might hearten the hearts of many, would not likely have any lasting value.

5. "Your vote doesn't count. Politicians like to say it counts because it is to their advantage to get everyone into

a crime not because of some vague and woolly invasion of a "right to privacy", but because it is an invasion of the property right of the person being wiretapped." a busybody mode. But, statistically, one vote in scores of millions makes no more difference than a single grain of sand on a beach. That's entirely apart from the fact that officials manifestly do what they want, not what you want, once they are in office."

Yes, unless there is an otherwise tie vote, your single ballot will have no effect on the actual winner. However, if the Libertarian Party can attain $5 \%$ of the vote, so they do not have to spend money merely to get on the ballot, this will mark an important gain in publicity for freedom. There was one occasion when Ron Paul ran for President, and came in second in a state ballot, and they announced those who came in first, third, fourth and fifth. If this did not give a boost to libertarianism, then nothing ever did or ever will.

\section{McElroy.}

Let us now begin our analysis of McElroy's (1996) views on the matter. She starts off on a very strong note, dealing with the following objection made to her: "If you could have cast the deciding vote against Hitler, would you have done so?' I replied, 'No, but I would have no moral objection to putting a bullet through his skull.' In essence, I adopted a stronger line -- a "plumb-line" as Benjamin Tucker phrased it -- on eliminating Hitler as a threat."

With all due respect, this author did no such thing. Instead, she evaded the question put to her; she changed the subject, entirely. The objection made no mention of alternatives to voting; it implicitly maintained that unless McElroy voted against Hitler, he would be in charge of our lives; that if she did violate 
her own precepts, we would have a much better ruler; perhaps someone on the order of Ludwig Erhard, the father of the German economic miracle. I find it highly problematic that she would not condescend to vote under these circumstances. By doing so, she could save millions of innocent lives. McElroy, suppose, just suppose, arguendo, that putting a bullet in Hitler's head was not an option. That the only choice you had was voting for Erhard; if not, Hitler takes power. Do you mean to sit there, stand there, and tell me you would seriously refrain from voting under these circumstances? If so, I applaud your adherence to your principles, but I am having a bit of difficulty in thinking they are libertarian principles.

McElroy continues: "I consider such a bullet to be an act of self-defense in a manner that a ballot could never be. The difference is that a bullet can be narrowly aimed at a deserving target; a ballot attacks innocent third parties who must endure the consequences of the politician I have assisted into a position of unjust power over their lives. Whoever puts a man into a position of unjust power -- that is, a position of political power -- must share responsibility for every right he violates thereafter."

Yes, if she voted for Erhard, McElroy would in some small, poetic sense be responsible for his misdeeds, and, to be sure, there would be some. But, they would pale into insignificance compared to the atrocities which Hitler committed. But we can dig deeper here. If placing someone in a position of unjust power makes you responsible for all his actions, what about giving up your wallet to the holdup man? When you do so, you enable him to purchase a bigger, better gun, which empowers him to prey on more and more people. Are you responsible for these subsequent crimes? Surely not. And yet, according to the logic of this author's remarks, you are. In the view of McElroy (2013), voting "would be akin to providing bullets to a person I knew would use his gun in a robbery." But this is precisely ${ }^{3}$ what the victim of the mugger does when he hands over his money to that worthy. Among other things, this criminal will purchase bullets with his ill-gotten gains.

States Bradford (1996) in this regard:

"For McElroy, if a candidate is elected, all who have voted for him become guilty of any crimes he might commit. This logic, it seems to me, would lead in very strange directions if it were applied to a voluntary association or corporation. By McElroy's argument, if she voted for someone to be chair of, say, her local Association of Voluntaryists, she would share guilt for any evil that individual might do in office, up to and including encouraging people to vote in political elections. Of course, such thinking, if adhered to by members of voluntary organizations, would simply eliminate any such association not run by administrative fiat."

Then, there is the dollar "vote." If we continue with the logic put forth by McElroy, we may not only not vote in the political sphere, we may not do so in the economic one either, since those with who we engage in commercial activities might not be pure, either. Bradford (1996) puts paid to this view as well:

"If one must investigate the antecedents of everything one buys and verify that it

${ }^{3}$ Well, loosely. 
was produced in accordance with one's ethical values, trade will halt and society will cease to exist."

McElroy, nothing loath, rejects my in effect attempt to shove Erhard down her throat:

"The question then shifted: 'If there had been no other strategies possible, would you have voted against Hitler?' This postulated a fantasy world which canceled out one of the basic realities of existence: the constant presence of alternatives. In essence, the question became 'if the fabric of reality were rewoven into a different pattern, would you still take the same moral stand.' (sic) Since my morals are derived from the nature of man and reality, it is not possible for me to answer this question. But my first response was to wonder what I would have been doing for the months and years that led to the momentous dilemma of scratching an ' $\mathrm{X}$ ' beside Adolph's name, or not. Or did I have no alternatives then either? I can only address the reality in which I live and, in a world replete with alternatives, I would not vote for or against Hitler.”

In other words, the challenge I pose to her is too theoretical for her tastes. This is somewhat surprising, since McElroy is a philosopher of no small skill. Yet, this discipline positively thrives on contrary to fact conditionals, even weirder ones $^{4}$ than the Hitler example that she herself poses. McElroy knows few equals in the entire field of philosophy, in my opinion; methinks it more than passing curious that in this one instance she would shrink from engaging in so phil-

${ }_{4}$ One need not read too far into the output of Nozick to come up with all sorts of examples. See Nozick () for example. osophical an enterprise as I am asking of her.

This author offers yet another criticism of voting: it strengthens "the structure of state power by accepting its authority..." She continues: "Good men acting through the state will strengthen its legitimacy and institutional framework. They will weaken the social conditions that allow social power to surge." Here, I must allow, she has a valid point. Participating in statist elections does indeed give an imprimatur to this hateful institution. However, her argument is only an empirical one. Yes, that is a debit, a cost, of entering the voting booth. But there are offsetting benefits, too. For example, if we are ever to peacefully rid ourselves of statism, we need more libertarians. How better to attract people to our banner than by such participation. Every four years, the public shifts its focus from beer, pizza, bowling and other such interests and actually pays attention to politics. This is a splendid opportunity to spread our message, and must be counted on the positive side of this empirical judgement. McElroy's prudential judgement leads her in one direction on this issue; mine in the other.

We now turn to a further consideration of the views on voting of McElroy (2013). She begins this essay of hers as follows:

"I oppose electoral voting on both moral and strategic grounds. In presenting the Voluntaryist case against electoral voting, however, I commonly encounter the slavery analogy as a counterargument in support of defensive voting. A classic formulation of it comes from Walter Block who argues, 'Suppose we were slaves, and the master offered us a vote for either Over- 
seer Baddy, who beat the crap out of us all the time, or Overseer Goody, who only beat us once in a while, and then more gently.' Block concludes that voting for Goody would be an act of self-defense and not an endorsement; voting is morally justified....

"My disagreement: the slave analogy focuses incorrectly on two issues. First, electoral voting is wrong only because the position being facilitated is unjust; by contrast, electing a clubhouse President is a neutral act. The focus should be on the office of politician or slave-master because that is what gives moral meaning to the vote. In other words, the key question is whether a libertarian could hold either position. If the answer is 'no', as I believe it is, then neither can a libertarian properly assist the politician or slave-master into an unjust position by voting for him. The office for which the vote is cast is the key moral question, and it should be the very beginning of any discussion on voting.

"Indeed, the most interesting aspect of the analogy for me is that it likens the libertarian politician to a slave-master. It implicitly concedes that political office is the moral equivalent of slave owning. This makes "voting for a libertarian" into an impossibility because no libertarian could run for political office any more than he could own slaves."

One must heartily agree with McElroy that no libertarian "could own slaves." And, yes, as McElroy insight-

${ }^{5}$ In making this statement, I abstract from the possibility of voluntary slavery. On this see Andersson, 2007; Block, 2001, 2002A, 2003, 2006; Frederick, 2014; Kershnar, 2003; Lester, 2000; Mosquito, 2014, 2015; Nozick, 1974, pp. 58, 283, 331; Steiner, 1994, pp. 232; Thomson, 1990, pp. 283-84. fully maintains, the non-libertarian politician is indeed akin to the slave owner: both violate the NAP. But how do we get from this undoubted truth to the conclusion that voting for the lesser of two evils, Goody instead of Baddy, is not a justified defensive maneuver? We simply do not.

McElroy (2013) continues: "The second incorrect focus: I may have a moral right to vote for a lesser evil within my own life but I have no similar right to facilitate the presence of that evil within someone else's life. I have no right to knowingly harm innocent others in the name of self-defense. And that's what voting does. The elected politician holds authority over everyone within a given jurisdiction, not just over me or over those who voted for him."

But this too is problematic. Presumably, all the slaves will prefer Goody to Baddy. ${ }^{6}$ Thus, their vote will not at all "harm innocent others." The very opposite will be the case. Electoral support for Goody will do the very opposite of "harm(ing) innocent others."

McElroy (2013) has other arrows in her quiver:

"Other problems quickly arise with the slavery analogy. Block and others postulate situations in which the 'voter' confronts real physical violence depending on how he votes or if he does not vote. (Block follows up the slavery analogy with "Now posit that a mugger held us at gun point, and demanded either our watch or our

${ }^{6}$ The only exception would be masochistic slaves. They are probably few in number, but with regard to them, and to them alone, McElroy's point is valid. In supporting Baddie, these folks do indeed worsen the situation of the normal slaves. Happily, they will likely lose out in this "election." 
wallet, and we gave him our time piece." Again, real physical violence is in play.) Electoral voters do not confront that situation. I have never voted and I have never been punished or even threatened with violence for abstaining. If I had been, if someone held a gun to my head, then I would prudently cast a ballot. In other words, the fact that I voted as a slave who was under threat of imminent violence says nothing about whether or not I would or should cast a voluntary ballot for which I would bear no real consequences if I tore it up. Frankly, I find the framework of violence within the slavery analogy to be peculiar. If voting is a morally neutral act, as the analogy wishes to argue, then why even introduce the atmosphere of violence to justify it? You don't justify the commission of other morally neutral acts, such as cheering one football team as opposed to another, by creating a framework of fear as the reason for doing so. Justifying the act of voting in the presence of violence seems to concede that there would be something wrong with the act sans such a threat.”

But this author just got finished telling us that she would not have voted against Hitler, presumably, even if Ludwig Erhard was the alternative. If I had to create a synonym for Hitler, surely it would be "violence, the initiation thereof." Indeed, her opposition to all politicians $^{7}$ is that they initiate (legal) violence, that is, violate the NAP. It comes with particular ill grace on her part to at this point object to the importation into this discussion of violence. This concept is part and parcel of all politics. This

\footnotetext{
7 She makes no exception for libertarian politicians such as You Know Who. For an alternative view, see Block (2012A).
}

discipline can be readily defined as the study of the use of violence.

Next up in the batter's box for McElroy is this statement: "Equally, the argument of self-defense itself seems to indicate that the politician (or the aspiring one) is committing an act of aggression against you. That's what self-defense means. Again, this concedes that there is something fundamentally wrong with a libertarian or anyone else running for political office or else the self-defense argument would not arise. And if there is something wrong with seeking political office, then there is something wrong with facilitating the rent-seeker. In the end, the slavery analogy also fails because it provides an unrealistically limited set of alternatives. In the analogy, the slave has no other means to ease his oppression other than by casting a vote. The slavery analogy never envisions or permits the possibility of a slave revolt on the spot or an escape attempt. The choice is always restricted to voting for Baddy or Goody, and this is simply unrealistic even in conditions of slavery."

There are difficulties here. Yes, this author and I agree that, apart from the libertarian politician, all those of this ilk are "committing an act of aggression." But McElroy has yet to demonstrate that a would-be or actual office holder must necessarily violate the NAP. What if he just votes against everything the government does? Suppose he never votes in the legislature at all, but merely uses his position in order to promote the freedom philosophy. It is unclear in the extreme why that would be a per se violation of the NAP. ${ }^{8}$ Nor is she correct in her asser-

8 For a critique of her use of the "rent seeker" see the following: Block, 2002B, 2015 
tion that "the slave has no other means to ease his oppression other than by casting a vote." He could commit suicide, he could run away, he could involve himself in an entirely justified slave rebellion.

Let this be the last quote of hers with which I will quarrel:

"Marginally free human beings, as North Americans still are, have a myriad of other strategies available through which to fight for their rights and freedom. I prefer non-violent resistance and the construction of parallel institutions that provide free-market alternatives to government 'services'."

I support McElroy in this. Indeed, I think her one of the pre-eminent contributors to the libertarian movement's "non-violent resistance" to statism. We part company only when politics, too, is considered in this repertoire.

\section{Ward}

In the view of Ward (1987): "But it is the anarchists who, for well over a century, have been the most consistent advocates of conscientiously staying away from the poll. Since anarchism implies an aspiration for a decentralised nongovernmental society, it makes no sense from an anarchist point of view to elect representatives to form a central government."

Not so, not so. There are several good and sufficient reasons why those who oppose government should yet want to take part in such an institution. For one, to become a fifth column; to undermine a hated organization from within. Do not warring countries, firms, clubs, attempt to spy upon one another? But, to do so, membership in the hated group is an all but requirement. For another, the better to utilize such a position as a megaphone; to be more able to broadcast one's anti-government message from within the bowels of that particular beast.

The present paper is animated by a libertarian, or anarcho-capitalist point of view. Ward (1987), in contrast, analyses the position of various anarchist philosophies greatly at variance from this one. For example, Marxist-anarchists, ${ }^{9}$ anarcho-syndicalists, and "Anarchistcommunists of the school of Kropotkin." Ward says of all of these: "Parliamentary elections were not merely irrelevant, they were a ruling-class conspiracy to divert workers' attention from the real struggle."

That all depends. It is based upon just how much time, effort and limited funds are allocated to such activities as the general strike, and how much to politics. There is an optimal allocation of resources, and Ward does not demonstrate that the ideal percentage to devote to politics should be zero. Perhaps some small amount should be allocated to this means.

Ward also addresses the libertarian anarchist, or anarcho-capitalist: "Finally, there is individualist anarchism proclaiming that it is absurd for individual people to surrender their right to run their own lives to an outside body. Objectors see 1 his as absurd selfishness and maintain that government is necessary to restrain our anti-social natures. Anarchists of all varieties respond with

9 They posit the "withering away of the state." Thus this is not the contradiction in terms that otherwise it would appear to be. 
William Morris's warning that no man is good enough to be another man's master."

Yes, yes, of course, from this vantage point to ultimate goal is to say good riddance, entirely, to the hated state. But, what about as a means toward that end? We have given reasons, supra, to think that this, too, might be an efficient intermediate step. None of them have been refuted by Ward.

Ward (1987) ends his essay on this note: "The non-voters will watch cynically as the politicians' lies and promises mount and the government goodnews machine rolls into action, quietly repeating the anarchist slogan: 'If voting changed anything they'd make it illegal."

Not so, not so. Ron Paul certainly changed at least some things. There have been bad presidents of the U.S., and relatively speaking, non-bad ones. ${ }^{10}$ Surely, this has made more than just a little bit of difference.

\section{Pugsley}

Pugsley (1995) is an open letter to his friend Harry Browne, asking the latter not to run for president on the Libertarian Party ticket.

This author starts off by conceding that "such a campaign would bring the free-market argument to hundreds of thousands of disenchanted individuals, spreading the truth that big government is their enemy and the sole source of America's social decay. And yes, it would be an extreme long-shot, but with luck, the Libertarians might actually win. If you became president, it would appear that you'd be positioned to strike a potentially mortal blow to the state. And

${ }^{10}$ At least from a libertarian point of view, there have been no good ones. even if you didn't win, reaching voters with the truth might exert tremendous pressure on politicians in the other parties, leading them to change the direction of government."

True, very true indeed. Why, then, not support this effort? Pugsley continues: "As I said, this is emotionally compelling. However, I ask you and all of our libertarian friends to re-examine the premises on which political action is founded before succumbing to its visceral appeal. Your charisma and persuasive power will attract the best and brightest minds of the libertarian world onto the political battlefield. If you are wrong, the potential injury to the cause of freedom could take a century to heal."

I don't know about "a century" but, yes, such a campaign is fraught with danger. But all acts, whether in politics or any other area of endeavor, come with risks. We continually live with uncertainty. However, the Libertarian Party (LP) has run in any number of presidential elections, and the sky has yet to fall in on this account. ${ }^{11}$

Every person in the lynch mob is as guilty as the person who pulls the rope.

This author then avers about the quest for liberty: "The most popular strategy is to use the political process to take control of the state apparatus. Those who choose this strategy believe that through education, political campaigning, and the voting booth, political power can be wrested from special interests, spendthrift politicians can be excised from government, and the state can be subdued. The Libertarian Party was founded to pursue such an agenda."

11 The LP has run candidates in presidential elections since 1972, and for governor, mayor, congress, local offices even before that time. 
There is some truth in this statement but it is exaggerated. To be sure, it would be a gigantic step in the direction of freedom if the LP were to succeed in being elected, and on a massive basis. However, most members of this political party do not expect any such occurrence to take place. By my own personal estimate, $99 \%$ of the hopes of members in this organization, such as me, the present author, is that the educational initiative is paramount: through this vehicle, we can reach more people than in any other way.

In contrast, says Pugsley (1995) the "non-political road is one some libertarians and all pure anarchists have followed." This is untrue. There is no more "pure anarchist" than Murray Rothbard. Yet, for many years he was a leader, no, pretty much the leader ${ }^{12}$ of the LP. There are dozens, no, scores, no, hundreds of other anarcho-capitalist libertarian who have been and are still, members of this organization.

Then, there is the old saw that "one vote doesn't matter." True, it is rare that there is an absolute tie, apart from votes for dog-catcher in small towns, and even there this is exceedingly rare. But this misses the educational point, entire. If focuses on the estimated $1 \%$ of the LP program: to actually be elected to office. ${ }^{13}$

Pugsley does concede that "a large voter turnout for a Libertarian candidate will send a message to the Democrat or Republican who does win." No truer words were ever said. At the beginning of the last century, the Socialist parties never won any election; none at all. And,

12 Unofficial.

13 Do not get me wrong. That would be nice. No, it would be magnificent. And the LP has indeed had some small successes in this direction. But most people, all rational persons, do not expect actual victory of the LP in any given election. yet, they did attract significant support from the electorate, and the two major parties eventually adopted virtually all of their policy planks. This cannot yet be said for the LP, ${ }^{14}$ but there always hope.

Here is the next sally of this author: "The voter implicitly agrees that 'whoever wins the election is entitled to regulate, tax, imprison, and kill." That is a bit of a stretch for "implicit" agreements. One might as well say, The purchaser of a ticket implicitly agrees that the team he roots for is entitled to win. There is a non sequitur in play in this statement of his.

He continues: "In a political democracy or republic, voting appoints a candidate to be your agent and implicitly sanctions him to aggress against others in the community. It is equivalent to saying that you have the right to give A permission to aggress against $B$. The anarchist argues that no individual, including you, has the right to give anyone else permission to aggress. According to the natural rights hypothesis, voting is an immoral act."

The best antidote to this claim has long ago been provided by spooner (1870):

"The Constitution has no inherent authority or obligation. It has no authority or obligation at all, unless as a contract between man and man. And it does not so much as even purport to be a contract between persons now existing. It purports, at most, to be only a contract between persons living eighty years ago. [This essay was written in 1869.] ...

“... actual voting is not to be taken as proof of consent, even for the time

${ }^{14}$ With the exception of marijuana legalization. 
being. On the contrary, it is to be considered that, without his consent having even been asked a man finds himself environed by a government that he cannot resist; a government that forces him to pay money, render service, and forego the exercise of many of his natural rights, under peril of weighty punishments. He sees, too, that other men practice this tyranny over him by the use of the ballot. He sees further, that, if he will but use the ballot himself, he has some chance of relieving himself from this tyranny of others, by subjecting them to his own. In short, he finds himself, without his consent, so situated that, if he use the ballot, he may become a master; if he does not use it, he must become a slave."

In short, contrary to Pugsley, the voter is not necessarily giving anyone permission to do anything.

Next, opines this author: "If you are elected, you'll be required to swear an oath to carry out the duties of the presidency and uphold the law, as specified in the Constitution. You and the voter don't set the contract, but your participation is your agreement to abide by its rules."

Again Spooner (1867) rides to the rescue in his refutation of Pugsley:

"... the oaths of all the other pretended agents of this secret band of robbers and murderers are, on general principles of law and reason, equally destitute of obligation. They are given to nobody; but only to the winds. The oaths of the taxgatherers and treasurers of the band, are, on general principles of law and reason, of no validity. If any tax gatherer, for example, should put the money he receives into his own pocket, and refuse to part with it, the members of this band could not say to him: You collected that money as our agent, and for our uses; and you swore to pay it over to us, or to those we should appoint to receive it.
You have betrayed us, and broken faith with us.

"It would be a sufficient answer for him to say to them:

"I never knew you. You never made yourselves individually known to me. I never game by oath to you, as individuals. You may, or you may not, be members of that secret band, who appoint agents to rob and murder other people; but who are cautious not to make themselves individually known, either to such agents, or to those whom their agents are commissioned to rob. If you are members of that band, you have given me no proof that you ever commissioned me to rob others for your benefit. I never knew you, as individuals, and of course never promised you that I would pay over to you the proceeds of my robberies. I committed my robberies on my own account, and for my own profit."

Our author also maintains that "All political action ultimately enhances state power... (It) gives a patina of respect to the very system of coercion and force that has enslaved the people." Here, Pugsley is onto something. Marking off the ballot is, and will be widely interpreted as, deference to government, something no self-respecting laissez faire anarchist can contemplate happily. But the same is true for walking on a government sidewalk, driving on one of its roads, using its post office or currency, even eating food, since most of it is subsidized by the state. But libertarianism is not a suicide pact. We are not required to not show reverence for government. As libertarians, our only requirement, the only one, is to refrain from violating the NAP. Voting does not do this. Therefore, it is compatible with this philosophy. ${ }^{15}$

15 For another critique of Puglsey (1995), see Prechter (1995). 


\section{Konkin}

Konkin (1995) is an attempt to undermine the contribution to this debate of Bradford (1995). I side completely with the latter in this dispute between them. What are the specifics? He starts out on the wrong foot, with an argument from authority:

"Politics and voting have had no place in Libertarian history for a century; to list every major figure in the Libertarian Movement between Josiah Warren and Frank Chodorov---and I will: Lysander Spooner, Benjamin Tucker, Albert J. Nock, H.L. Mencken, Rose Wilder Lane, Isabel Paterson, and Leonard Read---is to list anti-voters. There were exceptions, of course ... But the major figures, the 'hard-core' ones we remember, the ones whom others rallied around for a century and a half, opposed voting and running candidates. Thus, not voting is the norm, the standard, the orthodoxy which, if it is to be challenged, a compelling argument must be mounted.

Konkin continues: “...voting is statist (evil, to continue our ecclesiastical metaphor) and should be fought. Burn the polls ye sons of freedom! It is neither accident nor unideological spite that revolutionaries in the jungles and forests of the Third World actively oppose balloting to the extent of leading raids against polls and voters themselves... (The vote) ... still serves the function in aggregate of assisting the ruling class in selecting their representatives (not yours) to sort out the high-level conflicts they have not been able to settle like gentlemen (or ladies)."

This author is at least partially correct. Marking a ballot can indeed be reasonably interpreted as helping the statists. This is demonstrated by the fact that when there are too few people who do so, it is sometimes made compulso- ry. ${ }^{16}$ But there are so many other ways of giving the imprimatur to the statist ruling class, mentioned supra. The only issue for the libertarian is, Does this constitute a per se violation of the NAP. It is difficult to see how it does, particularly when it supports a certain medical doctor from Texas.

Konkin next launches a gratuitous and unfair attack on the LP: "What is a 'Libertarian' Party's function? To join the feeding trough dividing up the spoils of taxation, inflation and tariff protection, and to assist the rulers in deciding who is most fit to serve them. Why would any real libertarian devote an iota of his or her resources to that goal?"

Lord knows, the LP is not perfect. It has nominated presidential candidates whose adherence to the tenets of this philosophy are virtually non-existent. For example, Bob Barr. The membership of this political party are imperfect human beings. On the other hand, the libertarian credentials of Harry Brown and Ron Paul are beyond reproach. To say that the LP wants to "join the feeding trough" cannot be sustained, nor does Konkin offer any evidence for so unwarranted a contention.

Konkin next quotes Bradford as follows: "In our society, there are many means of convincing our fellows to change their opinions. We can try to educate them. We can try to stimulate others to educate them. We can set good examples by trying to live exemplary lives. We can organize debating societies. We can write book about feminism, or publish magazines. We can do research or explore the frontiers of social thinking. And, if we choose, we can run for office, using our campaign to spread the proposition that liberty is good.

16 Aly, 2017. 
Here is Konkin's response: "No, Editor Bradford, we cannot, whether or not we chose. An election campaign is not an educational endeavour, it is the opposite. Candidates cash in on the prior education done by activists, and then distort and dilute it to pick up a few marginal votes. No one who voted Libertarian ever was educated into Libertarianism via a political campaign."

Sorry, I can't resist. I have a two word refutation of Konkin on this point: "Ron Paul."

\section{Barnett}

According to Barnett (2012): "Voting (politically speaking) on its very face is immoral. Men of character cannot argue this, for voting pits one against another; this the desired effect sought by those who seek power. Voting allows for some to determine the fate of others, a fate that can only be accomplished by the use of force. Because of this truth, voting is the destroyer of freedom and liberty, not the protector of it."

Except for the last sentence, there is not a single fallacy in any of these claims. They are all true. However, the last sentence simply does not logically follow from these correct premises. Yes, sometimes voting does indeed destroy freedom. But, as we have seen, supra, it can also promote this value. For example, when it is done in self defense.

Barnett (2012) continues: "Even in the very best of situations, voting is still an unmitigated failure. The fact that any simple majority of individuals (mob) can determine an outcome that adversely affects the minority (mob rule) is against all natural rights. In the United State today, all who vote harm others so that they might benefit. By voting, they are also sanctioning theft of private property at the point of a gun, and the redistribution of that property to those who did not earn it."

But what about when the vote, whether for an office holder such as you know who, or a plebiscite, is to reduce taxes or unwarranted wealth-destroying regulations? Why is this "an unmitigated failure." To cast a ballot in this direction is the very opposite of "sanctioning theft of private property." Barnett vouchsafes us no answers to these important challenges.

Nor is it true, as this author asserts, that "those who vote legitimize all that governments do." Dr. No voted against hordes of illicit bills when he was in congress. Thus, he did the very opposite of legitimizing the evil that governments do. He lessened this. Those who argue to the contrary, such as Barnett, are in effect increasing government depredations, at least in this admittedly few cases. The correct analysis, it would appear is that good votes violate rights, while good ones do not at all.

The last contribution from this author we shall consider is this: "The problem in this country today is that all elections have winners and losers, but in every election, the politicians always win, and all the rest of us always lose. Obviously, voting guarantees that one or another politician wins."

But while, indeed, most politicians vote to reduce economic freedom, there are some who's acts increase it. Not all politicians are evil. Only the overwhelming majority. Thus, Barnett overgeneralizes in this condemnation of the entire category. 


\section{Conclusion}

There are many roads to liberty. Casey, McElroy, Ward, Pugsley, Konkin and Barnett to the contrary notwithstanding, politics is one of them. It is a valid one. It may or may not be the best one. That is a mere empirical issue, although the magnificent success of Ron Paul necessarily tips the balance in that direction. In this paper, however, I have not been concerned with that issue. Rather, I maintain that the ballot box vote does not violate any libertarian principle.

\section{References:}

Aly, Waleed. 2017. "Voting ShouldBe Mandatory." New York Times. January 19 https: / / www.nytimes.com/2017/01/ 19/opinion/voting-should-be-mandatory.html

Andersson, Anna-Karin. 2007. "An alleged contradiction in Nozick's entitlement theory." Journal of Libertarian Studies, Vol. 21, No. 3, Fall: 43-63; http://mises. org/journals/jls/21_3/21_3_3.pdf

Barnett, Gary D. 2012. "Voting: A Fool's Game!" October 16; https://www.lewrockwell.com/2012/10/gary-d-barnett/ voting-a-fools-game/

Block, Walter E. 1991. "Old Letters and Old Buildings," The Freeman Ideas on Liberty, March, pp. 96, http://www.fee. org/the_freeman/detail/old-letters-and-old-buildings/\#axzz2Txojgrts; https:// fee.org/articles/old-letters-and-old-buildings-2/

Block, Walter E. 1999. "Market Inalienability Once Again: Reply to Radin," Thomas Jefferson Law Journal, Vol. 22, No. 1, Fall, pp. 37-88; http://www.walterblock.com/publications/market_inalienability.pdf
Block, Walter E. 2001. "Alienability, Inalienability, Paternalism and the Law: Reply to Kronman," American Journal of Criminal Law, Vol. 28, No. 3, Summer, pp. 351-371; http://www.walterblock. com/publications/reply_to_kronman. pdf

Block, Walter E. 2002A. "A Libertarian Theory of Secession and Slavery," June 10; http://www.lewrockwell.com/block/ block15.html; http://libertariantruth. wordpress.com/2006/12/08/a-libertarian-theory-of-secession-and-slavery/

Block, Walter E. 2002B. "All Government is Excessive: A Rejoinder to 'In Defense of Excessive Government' by Dwight Lee," Journal of Libertarian Studies, Vol. 16, No. 3, pp. 35-82. http://www.mises. org/journals/jls/16_3/16_3_3.pdf

Block, Walter E. 2003. "Toward a Libertarian Theory of Inalienability: A Critique of Rothbard, Barnett, Gordon, Smith, Kinsella and Epstein," Journal of Libertarian Studies, Vol.17, No. 2, Spring, pp. 39-85; http://www.mises.org/journals / jls/17_2/17_2_3.pdf

Block, Walter E. 2006. "Epstein on alienation: a rejoinder" International Journal of Social Economics; Vol. 33, Nos. 3-4, pp. 241-260

Block, Walter E. 2012. "Rozeff on Privacy: A Defense of Rothbard." December 13; https://www.lewrockwell.com/1rc-blog/rozeff-on-privacy-a-defense-of-rothbard/

Block, Walter E. 2012A. Yes to Ron Paul and Liberty. New York: Ishi Press; http:// www.amazon.com/dp/4871873234; http://libertycrier.com/education/ walter-blocks-new-book-on-ron-paul/; http://libertyunbound.com/node/862 Block, Walter E. 2013A. "There Is No Right to Privacy." July 13; There Is No Right to Privacy http://archive.lewroc- 
kwell.com/2013/07/walter-block/there-is-no-right-to-privacy/

Block, Walter E. 2013B. Defending the Undefendable II: Freedom in all realms; Terra Libertas Publishing House.

Block, Walter E. 2015. "The rent seeker." Romanian Economic and Business Review, Vol. 10, No. 3, pp. 7-14, Fall; http://www.rebe.rau.ro/REBE_10_ 3_2015.pdf

Block, Walter E. 2016. "So-called Privacy Rights Are Incompatible with our Libertarian Philosophy." September 23; https://www.lewrockwell.com/lrc-blog/ called-privacy-rights-incompatiblelibertarian-philosophy/

Block, Walter E. 2017A. "Privacy Rights? No." May 1; https://www.lewrockwell. com/lrc-blog/privacy-rights-no/

Block, Walter E. 2017B. "Privacy rights? A Non-Response to Rozeff and Wenzel." May 6;

https://www.lewrockwell.com/lrc-blog/ privacy-rights-non-response-rozeff-wenzel/

Block, Walter, Stephan Kinsella and Roy Whitehead. 2006. "The duty to defend advertising injuries caused by junk faxes: an analysis of privacy, spam, detection and blackmail." Whittier Law Review, Vol. 27, No. 4, pp. 925-949; http://www. walterblock.com/wp-content/uploads / publications/block-etal_spam_whittier-2006.pdf; http://www.walterblock. com/wp-content/uploads/2009/06/faxesduty.pdf

Bonneau, Paul. 2012. "The privacy conundrum." December 17. http://strike-the-root.com/privacy-conundrum

Bradford, R.W. 1996. "Voting Is No Sin." Liberty, November. http://www.wendymcelroy.com/56bradfo.htm
Casey, Doug. 2017. "Top Five Reasons Not to Vote." December 25; https:// www.lewrockwell.com/2017/12/doug-casey/top-five-reasons-not-to-vote/

Frederick, Danny. 2014. "Voluntary Slavery," Las Torres de Lucca 4: 11537, http://www.lastorresdelucca.org/ index.php?option $=$ com_k2\&view =item $\&$ id=145:laesclavi-tud-voluntaria \&Itemid=24\&lang=en

Kershnar, Stephen. 2003. "A Liberal Argument for Slavery," Journal of Social Philosophy, 34

(4): 510-36.

Konkin, Sam. 1995. "Damnation of Bill Bradford." March; http://www.libertyunbound.com/sites/files/printarchive/ Liberty_Magazine_March_1995.pdf

Lester, Jan Clifford. 2000. Escape from Leviathan. St. Martin's Press. http://www.amazon.com/exec/obidos/ A S I N / 0312234163 / q - d \% 3 D 98 9845939/107-8070279-6411737

McElroy. Wendy. 1996. "Why I Would Not Vote Against Hitler." May; http://voluntaryist.com/articles/085b. html\#.WkL57FWnG70

http://www.wendymcelroy.com/hitler. htm

McElroy. Wendy. 2013. "The Faux Slavery Analogy to Voting." https: / / dailyanarchist.com/2013/07/31/the-faux-slavery-analogy-to-voting/

Mosquito, Bionic. 2014. "The Sanctity of Contract." April 19; http:/ / bionicmosquito.blogspot.com/2014/04/the-sanctity-of-contract.html

Mosquito, Bionic. 2015. "Walter Block, Specific Performance Contracts, and Abortion." July 12; http://bionicmosquito.blogspot.com/2015/07/walter-block-specific-performance.html 
Nozick, Robert. 1974. Anarchy, State and Utopia, New York: Basic Books, http:// www.amazon.com/Anarchy-State-Utopia-Robert-Nozick/dp/0465097200

Prechter, Robert. 1995. "Anti-Politics in Action." March; http://www.libertyunbound.com/sites / files / printarchive/Liberty_Magazine_March_1995.pdf Pugsley, John. 1995. "Voting." Liberty. March; http:/ /www.libertyunbound. com/sites / files / printarchive / Liberty_ Magazine_March_1995.pdf

Rothbard, Murray N. 1998 [1982]. The Ethics of Liberty, New York: New York University Press. http://www.mises. org/rothbard/ethics/ethics.asp

Spooner, Lysander. 1966[1870]. No Treason: The Constitution of No Authority and A Letter to Thomas F. Bayard, Larkspur, Colorado: Rampart College; http:/ / jim.com/treason.htm
Steiner, Hillel. 1994. An Essay on Rights, Oxford: Blackwell Publishers

Thomson, Judith Jarvis. 1990. The Realm of Rights, Cambridge, MA, Harvard University

Press

Ward, Colin. 1987. "The Case Against Voting." May 15; https:/ / theanarchistlibrary.org/library/colin-ward-the-case-against-voting

Wenzel, Robert. 2017. "The Privacy Rights of a Girl in Shower: The Private Property Society to the Rescue." May 3; http:/ / www.targetliberty.com/2017/05/ the-privacy-rights-of-girl-in-shower. html?utm_source $=$ feedburner\&utm medium $=$ email\&utm_campaign $=F e-$ ed\%3A+TargetLiberty+\%28Target+Liberty\%29 